\title{
Corporate Income Tax and Economic Distortions
}

\author{
GAËTAN NICODÈME
}

CESIFO WORKING PAPER NO. 2477

CAtegory 1: Public Finance

NOVEMBER 2008

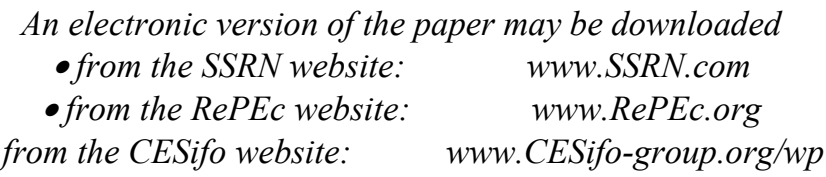




\title{
Corporate Income Tax and Economic Distortions
}

\begin{abstract}
As any non-lump-sum tax, corporate income taxation creates distortions in economic choices, reducing its efficiency. This paper reviews some of these domestic and international distortions and their most recent estimates from the economic literature. Distortions originating from income shifting between capital and labour sources, profit shifting across jurisdictions, the effects of taxation on business location and foreign direct investment are the major sources of distortions.
\end{abstract}

JEL Code: H25.

Keywords: corporate taxation, distortions, tax efficiency.

\author{
Gaëtan Nicodème \\ European Commission \\ Centre Emile Bernheim (Solvay Business School) \\ Belgium - Brussels \\ gaetan.nicodeme@ec.europa.eu
}

November 2008

(C) The author

A French version of this paper has been published in the issue 'Fiscalité Internationale' of the 'Bulletin de documentation du SPF Finances' in Belgium under the title 'Impôt des sociétés et distorsions'. The findings, interpretations, and conclusions expressed in this paper are entirely those of the authors. They should not be attributed to the European Commission. 


\section{Introduction.}

Tax efficiency is a well-known concept in public finance. This notion is part of a wider debate on the principles and criteria for taxation. In particular, the equity and efficiency criteria are at the heart of public choices when it comes to taxation. Except for a few exceptions - on which we will come back - corporate taxation raises very little controversy in terms of equity and the debate is focussing on aspects of tax efficiency instead. Indeed, as a non lump-sum tax, corporate taxation introduces distortions in the choices of economic agents. This paper does not seek to analyse exhaustively and in details each and any of the economic distortions generated by corporate taxes or international differences in corporate tax rates and bases. This would require a more rigorous and in-depth analysis. Instead, we wish to draw the attention of the reader on the most important distortions and on their most recent estimates from the economic literature.

The remainder of this article is organised as follows. The second section recalls the role of corporate taxation and the underlying economic reasons for having corporate income taxation. The third section introduces the domestic distortions of corporate taxation and the fourth section deals with international distortions linked to business and investment location and to profit shifting. Conclusions follow.

\section{Why do we have corporate taxation?}

Before reviewing the distortions created by corporate taxation, it is useful to discuss the rationales for having a corporate income tax in the first place. Under some assumptions in particular capital mobility - 'classic' economic models show that the optimal tax rate on capital for a small open economy is zero (Samuelson (1954), Tiebout (1956), Zodrow and Mieszkowski (1986), Wilson (1986)). Therefore, questioning the usefulness of corporate 
taxation is a worthy exercise. Since Gordon (1992), several authors have looked into this question and the underlying pros and cons for the existence of corporate taxation (Weichenrieder (2005), de Mooij (2005), Sørensen (2007)).

\subsection{Benefit principle.}

A first reason for having a corporate income tax is linked to the benefit principle. Akin to individuals, companies consume public goods - in particular infrastructures - and benefit from public interventions - such as education of workers or a judiciary system based on the rule-of-law. Therefore, it would seem normal that companies pay taxes as a compensation for those services. Some authors also argue that limited liability enjoyed by companies is an advantage that calls for a compensating tax. Those standpoints, even though attractive, are sometimes challenged because of the weak and rather indirect link between the use of those services and the determination of the corporate tax base, because companies are owned in fine by individuals who are also taxed, therefore introducing a risk of double-taxation, and because there are probably more direct ways of internalising the cost of the provision of those public goods, notably via user fees.

\subsection{Tax exporting.}

A second argument is based on questioning the assumption of perfect mobility of capital. Mobility is a much more complex topic in the real world than models suggest. Because of sunk costs or relocation costs, capital may sometimes be relatively immobile. It is the same if, as suggested by Lee (1997), there are complementarities between capital and a less mobile factor. For example, money on a bank account (in theory mobile) may be used to pay workers of a mining company (therefore immobile). If, in addition, a non-negligible share of companies are owned by foreign shareholders, tax authorities have an incentive to tax these companies and 'export' the tax burden on those shareholders (Mintz (1994), Huizinga and Nielsen (1997)). Wildasin (2003) develops such a model with convex costs of relocating 
capital (increasing with speed of relocation). He shows that the optimal capital tax rate at equilibrium is proportional to the share of foreign shareholding and inversely proportional to the degree of capital mobility. In an empirical study covering 34 European countries between 1996 and 2000, Huizinga and Nicodème (2006) show a strong positive relationship between the share of foreign shareholding in a country and the average corporate tax burden. Their estimate indicates that increasing the share of foreign ownership by one percentage point increases the average tax rate on companies by .43 percentage points on average. Imperfect capital mobility coupled with non-negligible foreign ownership would therefore explain the existence of corporate taxation.

\subsection{Treasury effects.}

A third rationale is linked to so-called treasury effects generated by foreign tax credits. Several large countries such as the US and the UK apply tax credit systems to relief doubletaxation on foreign income. Take a US multinational with a Belgian subsidiary. This subsidiary makes profit that is taxed at the Belgian corporate income tax at $33.99 \%$. When the US parent repatriates the profit of the subsidiary, the dividend is taxed at the US federal corporate tax rate of 35\%1. The US Company nevertheless receives a foreign tax credit of 33.99 on the tax already paid in Belgium, which it fully uses. The total tax burden is therefore $35 \%$ and fully determined by the tax rate applicable in the US. This example shows that with foreign tax credit systems in home countries, host countries are free to set their tax rates at the desired level (as long as they stay under the level of the home country) without having an impact on the total tax burden paid on repatriated dividends.

\subsection{Erosion of personal income taxes.}

A fourth argument is that corporate taxation is useful to avoid the attrition of personal income taxation. Indeed, in the absence of corporate income tax, it would be interesting for

\footnotetext{
${ }^{1}$ For the sake of simplicity, we ignore US state taxation and the withholding tax on the dividend.
} 
individuals to incorporate and therefore avoid taxes on their income. Corporate taxation is hence considered to be a backstop for personal income taxation. We will come back to this point.

\subsection{Political constraints.}

Finally, political constraints may play an important role. Corporations are often perceived by public opinion as entities making large profit and owned by wealthy investors, which generally qualifies them in the eyes of public opinion to bear an important share of the tax burden. In fact, corporate taxes represent only 3.4\% of GDP for the EU-27 in 2006 and $8.5 \%$ of total tax collected. The corporate tax base is also smaller than the personal income tax base or the VAT base for example2.

\section{Domestic distortions.}

\subsection{Deadweight loss.}

A first approach to evaluate economic distortions generated by corporate income taxation is to compute the deadweight loss (or Harberger Triangle). It represents the difference between the losses in consumer and producer surpluses and the tax collected. As a first proxy, deadweight loss as a percentage of tax collected is given by the formula $t \varepsilon / 2$, where $t$ is the corporate tax rate and $\varepsilon$ is the elasticity of the base to the rate. In 2008, the average corporate tax rate in the EU is $23.6 \%$. In their study on profit shifting in Europe, Huizinga and Laeven (2008) estimate the elasticity of the corporate tax base to the rate at .45 . This gives a deadweight loss in percentage of tax collected of 5.3\%.

\footnotetext{
2 See De Laet (2008).
} 


\subsection{Administrative and compliance costs.}

Administrative and compliance costs are important elements of tax efficiency. These costs are complex to estimate and very few data is available. They have been estimated at $10 \%$ of the collected tax in the US, of which $1 \%$ represents the administrative costs (Aaron and Gale (1983), Slemrod and Sorum (1984)). This estimate is comparable to similar studies that find administrative costs of 1.16\% for the UK (Godwin, 1995), 1.1\% for Australia (Pope, 1995), 1.6\% for France, .5\% for the US, .52\% for Sweden, .89\% for Spain (Carmona, Guiffès and Lépine, 2006) and 1.53\% for Czech Republic (Vitek and Pubal, 2002).

These costs vary also with the tax considered. For the UK, Godwin (1995) finds administrative costs of $.52 \%$ of collected taxes for corporate taxation, to be compared with $1.53 \%$ for personal income tax and social security contributions, $1.03 \%$ for VAT, .25\% for customs duties, and .12\% for taxes on fuels. For the Netherlands, de Kam (1998) finds relatively high ratios of $36.4 \%$ for wealth taxes, $17.6 \%$ for customs duties, $7.1 \%$ for environmental taxes, $6.2 \%$ for VAT, $5.1 \%$ for corporate taxation, and $4.8 \%$ for personal income taxation. Finally, in a study covering 700 EU companies, the European Commission (2004) finds ratios of $1.9 \%$ and $30.9 \%$ for large companies and SMEs respectively. Obviously, measures vary with the estimation technique, in particular with the assumptions on how to share common costs. Furthermore, those measures are averages and do not say anything on the marginal administrative cost of taxes.

\subsection{Distortions generated by reduced corporate tax rates.}

As political economy instrument, corporate taxation has been at the heart of debates about its neutrality vis-à-vis the size of companies. Many countries indeed apply reduced corporate tax rates for SMEs. Two debates are being hold. The first one is about the rationale for having differentiated tax rates for SMEs. The second debate, which we will not discuss in 
this paper, is linked to whether large companies pay a fair share of the tax burden3. Those two questions refer to both the equity and the efficiency aspects of corporate taxation.

The wish of tax authorities to implement measures to decrease the tax burden of SMEs may find its rationales in trying to reach the most efficient allocation of resources. Some market failures may indeed be detrimental to SMEs and authorities might be tempted to compensate them, possibly by using taxation (OECD, 1994). First, SME may have difficulties to access credit and may suffer from higher interest rates because of asymmetry of information regarding their financial situation, a lack of reputation because of their small size, and because of possible differences in their obligations compared to large companies with regards to informing investors, for example in accounting practices (Beck, Demirgüç-Kunt, and Maksimovic, 2005). Next, it is possible that SMEs face higher difficulties to create economies of scale, which generates higher average costs and a lower profitability. Third, SMEs may also face larger difficulties to meet their needs in terms of highly-skilled staff because of a lack of visibility, which may decrease their performance. In addition to these market failures, SMEs may also suffer from regulatory failures due to complex taxation systems. This complexity and their relative lack of expertise may put them in a more difficult position than large companies when trying to optimise their tax burden.

According to the OECD (1994), the arguments in favour of reduced corporate tax rates for SMEs are nevertheless weak. In particular, the measures to be taken may even make legislation been more complex, which increases costs for SMEs. Reduced corporate tax rates may also create distortions vis-à-vis the size of companies and act as a disincentive to grow. Alternative measures such as direct aid or a better functioning of credit markets are considered as more efficient.

\footnotetext{
${ }^{3}$ See Nicodème (2007) for a recent discussion.
} 


\subsection{Distortions generated by a shift to labour.}

Another important distortion created by corporate taxation is the one induced on labour markets. This distortion is well-known in theory but is generally absent from the political debate. Economic theory shows that, under the assumption of mobility of capital, the incidence of the corporate tax is fully borne by labour (Gordon, 1986). Furthermore, this literature insists that capital flight reduces labour productivity and, in fine, wages. Hence, this creates an additional distortion which could be avoided if labour would be taxed directly.

Recently, Arulampalam, Devereux, and Maffini (2007) have investigated this issue using a panel of more than 50,000 companies in nine European countries over 1996-2003. Their results suggest a validation of the theory as each additional euro of corporate tax reduces wages by 92 eurocents in the long-run. Therefore, the incidence of corporate taxation falls almost entirely on labour.

\subsection{Distortions created by a shift from personal to corporate income taxes..}

One last domestic economic distortion is linked to the possibility for some agents to requalify their labour income into capital income and vice versa. It is indeed possible for entrepreneurs to incorporate and to substitute in this way their labour income with corporate income, which is taxed at lower rates. This issue has mainly been studied for the United States. Makie-Mason and Gordon (1997) use data on the share of companies in capital between 1956 and 1986 and find that this share is positively influenced by the difference between the personal income tax and corporate income tax rates when companies are making profit. Goolsbee (2004) carries out a sectoral study for the US in 1992 and finds that an increase in the corporate tax rate by a tenth of a percent decreases the share of incorporated companies in the total number of firms by .25 percentage points and their share in sales and employment by .07 and .15 percentage points respectively. 
For Europe, studies show similar effects. Fuest and Weichenrieder (2002) look at the share of corporate savings in total savings for 17 OECD countries between 1985 and 1997 and find that this share is positively related to the difference between personal and corporate income tax rates. Their results suggest that for each reduction in the corporate tax rate by one percentage-point, the share of corporate savings increases by $2.6 \%$. Recently, de Mooij and Nicodème (2008) have used data on incorporation covering 17 European countries and 60 sectors between 1997 and 2003. Their study shows that the difference between the two tax rates exerts a significant positive impact on incorporation. The semi-elasticity in their study is 1 , meaning that an increase by one percentage-point in the difference between the two rates leads on average to an increase in incorporation by $1 \%$.

This result has important consequences for tax policy. Between 12 and 21\% of corporate income tax collected can be attributed to the difference between the average personal and corporate income tax rates. This difference is about 21 percentage points for Europe. Its increase has contributed to increase the ratio of corporate tax collected on GDP by $.25 \%$. Next, it also means that some of the consequences of corporate tax competition will materialise into an erosion of personal income taxes as many entrepreneurs take advantage of decreasing corporate tax rates to incorporate. The estimates by de Mooij and Nicodème (2008) show the importance of this distortion as each ex-ante increase of corporate taxes by 1 euro bring only 76 cents. The difference is shifted to personal income taxes.

\section{International distortions.}

The efficiency of corporate income taxation and the distortions it generates are even more acute in an international context. The concepts of capital import neutrality and capital export neutrality are useful guides in this respect. Capital Export Neutrality (CEN) states that the tax burden shall be independent from the location of activities that generate taxable profit. 
This is for example the case for residence-based taxation which will tax a specific investor at the same rate for all his/her investment wherever they occur. Location decisions are therefore not affected by taxes and, provided the pre-tax rate of return is the same everywhere, taxes will not distort capital allocation decisions. However, investors located in different countries will face different post-tax rates of return. Inversely, Capital Import Neutrality (CIN) states that the tax burden shall not depend on the location of investors. This is for example the case of source-based taxes. In this case, the post-tax rates of returns of all investors doing business in one specific country will be equalised. However, the location of investment across countries will be affected by taxes. It is widely admitted that, in application of the production efficiency theorem of Diamond and Mirrlees (1971), Capital Export Neutrality is preferable to Capital Import Neutrality.

Nevertheless, Devereux (2008) underlines that, in a global economy, these principles can only be reached by achieving full harmonisation. Hence, far from reaching neutrality, corporate taxation also creates distortions at the international level. To categorise these distortions, it is useful to start with a decision tree for companies as the one defined in Devereux (2007). In this framework, companies face four consecutive decisions. First, companies need to decide whether to produce at home and export or to produce abroad. This decision seems to be largely independent from tax considerations. Second, conditioned to having decided to produce abroad, companies need to decide in which country to locate foreign production. Average effective corporate tax rates seem to influence this decision. Next, conditioned on the two previous choices, companies need to decide how much to invest in the chosen country. Marginal effective corporate tax rates seem to have an influence on this outcome. Finally, conditioned to the three previous choices, the last decision is where to show taxable profit by shifting it across jurisdictions. Here, statutory corporate tax rates may have an impact. We will now review distortions linked to these choices. 


\subsection{Distortions linked to company location.}

Many factors determine the location of foreign subsidiaries, such as market size, labour costs, productivity, legal environment or distance to home country. However, Devereux and Griffith (1998) analyse location decisions of US Multinationals in four European countries between 1980 and 1994 and show that location choice are also influenced by average effective tax rates. Buettner and Ruf (2007) find that statutory tax rates influenced location decisions of German multinationals in 18 European countries between 1996 and 2003. Overesch and Wamser (2008) also find a similar result for the location of these German Multinationals in ten new Member States between 2004 and 2007, using the average corporate effective tax rate.

A growing economic literature shows that international rules for taxation of crossborder operations play an important role. This is for example the case for tax credits (see Hines, 1996). In a recent paper, Barrios, Huizinga, Laeven and Nicodème (2008) analyse the decisions of European groups on where to locate foreign subsidiaries, using the various aspects of international taxation. They find that both the local tax in the host country and the tax in the home country matter. The analysis of the impact of corporate taxation on the location of companies requires the use of regression models for limited dependent variables, such as probit and logit models, which makes interpretation of results more difficult. However, using preliminary results from Barrios, Huizinga, Laeven and Nicodème (2008), a one percentage-point increase in the effective4 tax rate of companies (i.e. from a sample average of $35.3 \%$ to $36.3 \%$ ) reduces the probability to locate a foreign subsidiary in a specific country by $3.96 \%$, all other things equal. This coefficient is only $2.93 \%$ if one takes into

\footnotetext{
${ }^{4}$ The definition here is different from the one of Devereux-Griffith. By effective, the authors mean the implicit tax rate that is applicable to repatriated profit, taking into account all elements of host country and home country taxation, including double-tax relief when applicable.
} 
account the host country tax rate only, which confirms that doing so underestimates the impact of taxation on business location.

\subsection{Distortions to investment.}

The link between taxation and foreign direct investment has been the subject of a myriad of studies that differ in the tax variables considered, the FDI data used and the estimation techniques. It is therefore unsurprising that their results show a large variation. De Mooij and Ederveen (2003, 2006) carry out a meta-analysis of these many studies and find a mean value of 2.9 for the semi-elasticity of foreign direct investment to effective corporate tax rates. This means that increasing the corporate effective tax rate by one percentage point would decrease foreign direct investment by $2.9 \%$

Following the technique of de Mooij (2005), we can estimate the size of this distortion. Under the hypothesis that foreign investment does not crowd out domestic investment, the effect of an increase in corporate taxation shall exclusively materialise in decreased foreign direct investment. According to Huizinga and Nicodème (2006), the share of foreign ownership in the total assets of companies in Europe is $21.1 \%$. This means that a one percentage point increase in the effective corporate tax rate will reduce the corporate tax base by $.61 \%$ (i.e. -2.9 x 21.1\%). Furthermore, de Mooij (2005) finds that a one percentage point increase in the statutory corporate tax rate leads on average to an increase in the effective corporate tax rate by $.88 \%$. If one applies this value, a one percentage-point increase in the statutory effective tax rate shall decrease the corporate tax base by $.54 \%$ (i.e. .61\% x .88). Since, the corporate tax base is taxed on average at $23.6 \%$, this means that the ex-post loss in taxes is $12.7 \%$ of the ex-ante collected tax revenues (i.e. .54 x $23.6 \%$ ). In other words, an ex-ante increase in the corporate statutory tax rate by one percentage-point will lead to an increase in tax collected by $.873 \%$ only when taking into account the reduction in foreign direct investment. 


\subsection{Distortions due to profit shifting.}

Finally, profit shifting across jurisdiction constitutes one important sources of distortion, but also one that is difficult to analyse. Several authors, among which Grubert and Muti (1991) and Hines and Rice (1994) show that there is a negative correlation between reported corporate profit and the corporate tax rate of the country where the profit is reported. This suggests that Multinationals have the possibility to transfer profit within the corporate group from high-tax countries to the low-tax jurisdictions.

Huizinga and Laeven (2008) use a panel of company data in 21 European countries to estimate the size and cost of profit shifting activities. Their estimates confirm that profit shifting activities are sizeable, varying from a gain corresponding to $22.4 \%$ of the corporate tax base for Hungary (but computed on a small tax base) to a loss of $13.6 \%$ for Germany. Whereas Grubert and Muti (1991) and Hines and Rice (1994) estimate the semi-elasticity of the corporate tax base to corporate tax rate at -2.3 and -2.5 respectively, Huizinga and Laeven (2008) find a lower value of -1.31 . This suggests that each increase in the statutory corporate tax base by one percentage point decreases reported profit by multinationals by $1.31 \%$. It is arduous to estimate the percentage of companies that, being part of a group, have the possibility to transfer their profit. De Mooij (2005) estimated this percentage at $50 \%$ for The Netherlands. From Huizinga, Laeven and Nicodème (2008), we see that this ratio seems to be applicable to Europe5, which would mean that an ex-ante increase of the corporate tax rate by one percentage-point leads to a 'tax flight' of about $17.2 \%$ of the planned tax collection (i.e. $1.31 \% \times 50 \%$ x 26.3\%). This is a sizeable distortion.

Profit shifting occurs via several channels. For instance, companies may artificially transfer debt. A company located in a low-tax country may lend to a related company located in a high-tax country. This latter will pay interest - taxed at a lower corporate tax rate - to the

\footnotetext{
${ }^{5}$ Limiting their sample to foreign subsidiaries reduces the number of observations by about half.
} 
first and can deduct these payments from its taxable profit (that is subject to a high corporate tax rate). At the level of the group, the total tax burden will be reduced thanks to this profit shifting. Several studies analyse this phenomenon, in particular for the United States (MacKie-Mason (1990), Gordon and Lee (2001), Graham (2000)). Some other studies look at the debt policy of Multinationals with parent companies or subsidiaries in the US (Hines and Hubbard (1990), Collins and Shackelford (1992), Froot and Hines (1992), Grubert (1998), Altshuler and Grubert (2003) and Desai, Foley and Hines (2004)) and find that their debt policy is consistent with tax-minimizing strategies.

Analysing a panel of German multinational companies, Ramb and Weichenrieder (2004), Mintz and Weichenrieder (2005) and Overesch and Wamser (2008) all find a positive effect of the tax rate on the leverage of companies. Jog and Tang (2001) for Canadian data and Moore and Ruane (2005) for European data also find such an impact. Huizinga, Laeven and Nicodème (2008) use company data for 32 European countries between 1994 and 2003. They link debt policy with effective taxation of companies, taking into account the rules applicable to international taxation. Their results suggest that for stand-alone companies, an increase in the effective tax rate by one percentage-point increases the ratio of debt to assets by $.18 \%$. The impact is larger for Multinationals as it reaches $.24 \%$ for two equal-size companies (with one foreign subsidiary) within the same group. The estimates by Overesch and Wamser (2008), Desai, Foley and Hines (2004) and Huizinga, Laeven and Nicodème (2008) are very similar in size.

The other important channel for shifting profit across jurisdictions is transfer pricing. Those refer to prices and rates applicable to intra-group operations. By applying intra-group prices and rates that differ from market conditions, multinational groups are able to increase or decrease reported profit in specific countries. Despite strict regulations and monitoring by tax authorities, the economic literature has found that some empirical results are in line with 
the existence of such practices. For example, Clausing (1993, 2003) and Swensson (2001) find evidence of transfer pricing activities for a panel of US multinationals. Barteslman and Beetsma (2003) find similar results for 22 OECD countries between 1979 and 1997. Their semi-elasticity of the tax base to an increase in the tax rate by one percentage point is in this case -3.5.

\section{Conclusions.}

Corporate taxation has fuelled many debates about both its usefulness and odds of survival and the distortions it creates. Those are of both domestic and international nature. A review of the empirical economic literature ranks income shifting between capital and labour sources at the top of the list of distortions. Profit shifting across jurisdictions set up another source of distortions. Finally, the effects of taxation on business location and foreign direct investment are a third source of distortions. 


\section{References.}

Aaron H. and Gale, W. (1983). Economic Effects of Fundamental Tax Reforms, Brooking Institution Press.

Altshuler, R., and Grubert, H. (2003). Taxes, repatriation strategies and multinational financial policy, Journal of Public Economics, 87: 73-107.

Arulampalam, W.; Devereux, M. and Maffini, G. (2007). The Incidence of Corporate Income Tax on Wages, Oxford University Centre for Business Taxation Working Papers, 07/07.

Barrios, S., Huizinga, H., Laeven, L. and Nicodème, G. (2008). International Taxation and Corporate Location Decisions, Mimeo.

Bartelsman, E.J. and Beetsma, R.M.W.J. (2003). Why Pay More? Corporate Tax Avoidance Through Transfer Pricing in OECD Countries, Journal of Public Economics, 87: 2225-2252.

Beck, T.; Demirgüç-Kunt, A. and Maksimovic, V. (2005). Financial and Legal Constraints to Growth: does firm size matter? Journal of Finance. 60(1): 137-177.

Buettner, T. and Ruf, M. (2007). Tax Incentives and the Location of FDI: evidence from a panel of German multinationals, International Tax and Public Finance, 14(2):151-164.

Carmona, J., Gouiffès, P-F. and Lépine, J-L. (1999). Mission d'Analyse Comparative des Administrations Fiscales. Inspection Générale des Finances, Paris. http://alize.finances.gouv.fr/2003/rapport.pdf

Clausing, K.A. (1993). The Impact of Transfer Pricing on Intrafirm Trade, in Studies in International Taxation, Giovannini, A., Hubbard, R.G. and Slemrod, J. editeurs, University of Chicago Press.

Clausing, K.A. (2003). Tax-Motivated Transfer Pricing and US Intrafirm Trade Prices, Journal of Public Economics, 87: 2207-2223.

Collins, J.H., and Shackelford, D.A. (1992). Foreign tax credit limitations and preferred stock issuances, Journal of Accounting Research, 30: 103-124.

De Kam, F. (1998). The Netherlands, in The Tax System in Industrialized Countries, K. Messere editor, Oxford University Press.

De Laet, J-P (2008). Tendances récentes dans l'évolution des systèmes fiscaux en Europe, Forthcoming in Bulletin de Documentation du SFP Finances.

Desai, M.A., Foley, C.F. and Hines, J.R. (2004). A Multinational Perspective on Capital Structure Choice and Internal Capital Markets, Journal of Finance, 59:2451-2487.

Devereux, M.P. and Griffith, R. (1998). Taxes and the Location of Production: evidence from a panel of US multinationals, Journal of Public Economics, 68:335-367.

Devereux, M.P. (2007). The Impact of Taxation on the Location of Capital, Firms and Profit: a Survey of Empirical Evidence, Oxford University Centre for Business Taxation Working Papers, 07/02.

Devereux, M.P (2008). Taxing Foreign Profit: Economic Principles and Feasibility, Mimeo.

Diamond, P. and Mirrlees, J. (1971). Optimal Taxation and Public Production I: Production Efficiency, American Economic Review, 8-27.

European Commission (2004). European Tax Survey. Taxation Papers, $\mathrm{n}^{\circ} 3$. 
Froot, K.A, and Hines, J.R. (1995). Interest allocation rules, financing patterns, and the operation of U.S. multinationals, in: Feldstein, M., Hines, J.R., Hubbard, R.G. (Eds.), The Effect of Taxation on Multinational Corporations. University of Chicago Press, Chicago, pp. 277-307.

Fuest, C. and Weichenrieder, A. (2002). Tax Competition and Profit Shifting: On the Relationship between Personal and Corporate Tax Rates, Ifo Studien: Zeitschrift fur Empirische Wirtshaftsforschung, 48: 611-632.

Godwin, M. (1995). The compliance costs of the United Kingdom tax system, in Tax Compliance Costs Measurement and Policy, edited by C. Sandford, 73-100. Bath: Fiscal Publications.

Goolsbee, A. (2004). The Impact of the Corporate Income Tax: Evidence from State Organizational Form Data, Journal of Public Economics, 88: 2283-2299.

Gordon, R. (1986). Taxation of Investment and Savings in a World Economy, American Economic Review, 76: 302-308.

Gordon, R. (1992). Can Capital Income Taxes Survive in Open Economies? Journal of Finance, 47: 1159-1180.

Gordon, R.H., and Lee, Y. (2001). Do taxes affect corporate debt policy? Evidence from U.S. corporate tax return data, Journal of Public Economics, 82: 195-224.

Graham, J.R. (2000). How big are the tax benefits of debt? Journal of Finance, 55: 19011941.

Grubert, H. and Muti, J. (1991). Taxes, Tariffs and Transfer Pricing in Multinational Corporation Decision Making, Review of Economics and Statistics, 80(3): 365-373.

Grubert, H. (1998). Taxes and the division of foreign operating income among royalties, interest, dividends and retained earnings, Journal of Public Economics, 68: 269-290.

Hines, J.R., and Hubbard, R.G. (1990). Coming home to America: dividend repatriations by U.S. multinationals. In: Razin, A., Slemrod, J., (Eds.), Taxation and the Global Economy. University of Chicago, Chicago, 161-200.

Hines, J. R. (1996). Altered states: Taxes and the Location of Foreign Direct Investment in America, American Economic Review, 86(5): 1076-1094.

Hines, J.R. and Rice, E.M. (1994). Fiscal Paradise: Foreign Tax Havens and American Business, Quarterly Journal of Economics, 109:149-182.

Huizinga, H. and Nielsen, S.B. (1997). Capital Income and Profit Taxation with Foreign Ownership of Firms, Journal of International Economics, 42:149-165.

Huizinga, H. and Nicodème, G. (2006). Foreign Ownership and Corporate Income Taxation: an empirical evaluation, European Economic Review, 50: 1223-1244.

Huizinga, H. and Laeven, L. (2008). International Profit Shifting within Multinationals: a Multi-Country Perspective, Journal of Public Economics, 92: 1164-1182.

Huizinga, H., Laeven, L. and Nicodème, G. (2008). Capital Structure and International Debt Shifting, Journal of Financial Economics, 88: 80-118.

Jog, V., and Tang, J. (2001). Tax reforms, debt shifting and tax revenues: multinational corporations in Canada, International Tax and Public Finance, 8: 5-25. 
Lee, K. (1997). Tax Competition with Imperfectly Mobile Capital, Journal of Urban Economics, 42:222-242.

MacKie-Mason, J.K. (1990). Do taxes affect corporate financing decisions? Journal of Finance, 45: 1471-1493.

Mackie-Mason, J.K. and Gordon, R.H. (1997). How Much Do Taxes Discourage Incorporation?, Journal of Finance, 52(2): 477-505.

Mintz, J. M. (1994). Is There a Future for Capital Income Taxation? Canadian Tax Journal, 42(6): 1469-1503.

Mintz, J.M. and Weichenrieder, A.J. (2005). Taxation and the financial structure of German outbound FDI, CESifo Working Paper, 1612.

Mooij, R.A. de and Ederveen, S. (2003). Taxation and Foreign Direct Investment: A Synthesis of Empirical Research, International Tax and Public Finance, 10: 673-693.

Mooij, R.A. de (2005). Will Corporate Income Taxation Survive? De Economist, 153(3): 277301.

Mooij, R.A. de and Ederveen, S. (2006). What a Difference Does it Make? Understanding the Empirical Literature on Taxation and International Capital Flows, Economic Paper, 261, European Commission.

Mooij, R.A. de and Nicodème, G. (2008). Corporate Tax Policy and Incorporation in the EU, International Tax and Public Finance, 15: 478-498.

Moore, P.J., Ruane, F.P. (2005). Taxation and the financial structure of foreign direct investment. Trinity College Dublin, IIIS Discussion Paper, 88.

Nicodème, G. (2007). Do Large Companies Have Lower Effective Corporate Tax Rates? A European Survey, CEB Working Paper, 07-001, Université Libre de Bruxelles, Solvay Business School, Centre Emile Bernheim (CEB).

OECD. (1994), Taxation and small businesses, Paris.

Overesch, M. and Wamser, G. (2008). The Effects of Company Taxation in EU Accession Countries on German Multinationals, Mimeo.

Pope, J. (1995). The Compliance Costs of Major Taxes in Australia, in Tax Compliance Costs Measurement and Policy, edited by C. Sandford, 101-25. Bath: Fiscal Publications.

Ramb, F. and Weichenrieder, A.J. (2004). Taxes and the financial structure of German inward FDI, CESifo Working Paper, 1355.

Samuelson, P. A. (1954). The Pure Theory of Public Expenditure, Review of Economics and Statistics, 36(4): 387-389.

Slemrod, J. and Sorum, N. (1984). The Compliance Cost of US Individual Income Tax System, National Tax Journal, 37(4): 461-474.

Sørensen, P.B. (2007). Can Capital Income Taxes Survive? CESifo Economic Studies, 53(2): 172-228.

Swensson, D.L. (2001). Tax Reforms and Evidence of Transfer Pricing, National Tax Journal, 54(1): 7-26.

Tiebout, C.M. (1956). A Pure Theory of Local Expenditures, Journal of Political Economy, 64(5): 416-424. 
Vitek, L and Pubal, K (2002). Evaluation of the Effectiveness of the Tax Collection - The Case of the Czech Central and Local Governments, United Nations Public Administration Network, http://unpan1.un.org/intradoc/groups/public/documents/NISPAcee/UNPAN004338.pdf

Weichenrieder, A.J. (2005). (Why) Do We Need Corporate Taxation? CESifo Working Paper, 1495.

Wildasin, D. (2003). Fiscal Competition in Space and Time, Journal of Public Economics, 87:2571-2588.

Wilson, J.D. (1986). A Theory of Interregional Tax Competition, Journal of Urban Economics, 19(3): 296-315.

Zodrow, G.R and Mieszkowski, P. (1986). Pigou, Tiebout, Property Taxation, and the Underprovision of Local Public Goods, Journal of Urban Economics, 19(3): 356-370. 


\section{CESifo Working Paper Series}

for full list see www.cesifo-group.org/wp

(address: Poschingerstr. 5, 81679 Munich, Germany, office@cesifo.de)

2417 Valentina Bosetti, Carlo Carraro, Alessandra Sgobbi and Massimo Tavoni, Modelling Economic Impacts of Alternative International Climate Policy Architectures. A Quantitative and Comparative Assessment of Architectures for Agreement, October 2008

2418 Paul De Grauwe, Animal Spirits and Monetary Policy, October 2008

2419 Guglielmo Maria Caporale, Christophe Rault, Robert Sova and Anamaria Sova, On the Bilateral Trade Effects of Free Trade Agreements between the EU-15 and the CEEC-4 Countries, October 2008

2420 Yin-Wong Cheung and Daniel Friedman, Speculative Attacks: A Laboratory Study in Continuous Time, October 2008

2421 Kamila Fialová and Ondřej Schneider, Labour Market Institutions and their Effect on Labour Market Performance in the New EU Member Countries, October 2008

2422 Alexander Ludwig and Michael Reiter, Sharing Demographic Risk - Who is Afraid of the Baby Bust?, October 2008

2423 Doina Maria Radulescu and Michael Stimmelmayr, The Welfare Loss from Differential Taxation of Sectors in Germany, October 2008

2424 Nikolaus Wolf, Was Germany ever United? Evidence from Intra- and International Trade 1885 - 1933, October 2008

2425 Bruno S. Frey, David A. Savage and Benno Torgler, Noblesse Oblige? Determinants of Survival in a Life and Death Situation, October 2008

2426 Giovanni Facchini, Peri Silva and Gerald Willmann, The Customs Union Issue: Why do we Observe so few of them?, October 2008

2427 Wido Geis, Silke Uebelmesser and Martin Werding, Why go to France or Germany, if you could as well go to the UK or the US? Selective Features of Immigration to four major OECD Countries, October 2008

2428 Geeta Kingdon and Francis Teal, Teacher Unions, Teacher Pay and Student Performance in India: A Pupil Fixed Effects Approach, October 2008

2429 Andreas Haufler and Marco Runkel, Firms' Financial Choices and Thin Capitalization Rules under Corporate Tax Competition, October 2008

2430 Matz Dahlberg, Heléne Lundqvist and Eva Mörk, Intergovernmental Grants and Bureaucratic Power, October 2008 
2431 Alfons J. Weichenrieder and Tina Klautke, Taxes and the Efficiency Costs of Capital Distortions, October 2008

2432 Andreas Knabe and Ronnie Schöb, Minimum Wage Incidence: The Case for Germany, October 2008

2433 Kurt R. Brekke and Odd Rune Straume, Pharmaceutical Patents: Incentives for R\&D or Marketing?, October 2008

2434 Scott Alan Carson, Geography, Insolation, and Institutional Change in $19^{\text {th }}$ Century African-American and White Stature in Southern States, October 2008

2435 Emilia Del Bono and Daniela Vuri, Job Mobility and the Gender Wage Gap in Italy, October 2008

2436 Marco Angrisani, Antonio Guarino, Steffen Huck and Nathan Larson, No-Trade in the Laboratory, October 2008

2437 Josse Delfgaauw and Robert Dur, Managerial Talent, Motivation, and Self-Selection into Public Management, October 2008

2438 Christian Bauer and Wolfgang Buchholz, How Changing Prudence and Risk Aversion Affect Optimal Saving, October 2008

2439 Erich Battistin, Clara Graziano and Bruno Parigi, Connections and Performance in Bankers' Turnover: Better Wed over the Mixen than over the Moor, October 2008

2440 Erkki Koskela and Panu Poutvaara, Flexible Outsourcing and the Impacts of Labour Taxation in European Welfare States, October 2008

2441 Marcelo Resende, Concentration and Market Size: Lower Bound Estimates for the Brazilian Industry, October 2008

2442 Giandomenico Piluso and Roberto Ricciuti, Fiscal Policy and the Banking System in Italy. Have Taxes, Public Spending and Banks been Procyclical in the Long-Run? October 2008

2443 Bruno S. Frey and Katja Rost, Do Rankings Reflect Research Quality?, October 2008

2444 Guglielmo Maria Caporale, Antoaneta Serguieva and Hao Wu, Financial Contagion: Evolutionary Optimisation of a Multinational Agent-Based Model, October 2008

2445 Valentina Bosetti, Carlo Carraro and Massimo Tavoni, Delayed Participation of Developing Countries to Climate Agreements: Should Action in the EU and US be Postponed?, October 2008

2446 Alexander Kovalenkov and Xavier Vives, Competitive Rational Expectations Equilibria without Apology, November 2008 
2447 Thiess Buettner and Fédéric Holm-Hadulla, Cities in Fiscal Equalization, November 2008

2448 Harry H. Kelejian and Ingmar R. Prucha, Specification and Estimation of Spatial Autoregressive Models with Autoregressive and Heteroskedastic Disturbances, November 2008

2449 Jan Bouckaert, Hans Degryse and Thomas Provoost, Enhancing Market Power by Reducing Switching Costs, November 2008

2450 Frank Heinemann, Escaping from a Combination of Liquidity Trap and Credit Crunch, November 2008

2451 Dan Anderberg, Optimal Policy and the Risk Properties of Human Capital Reconsidered, November 2008

2452 Christian Keuschnigg and Evelyn Ribi, Outsourcing, Unemployment and Welfare Policy, November 2008

2453 Bernd Theilen, Market Competition and Lower Tier Incentives, November 2008

2454 Ondřej Schneider, Voting in the European Union - Central Europe's Lost Voice, November 2008

2455 Oliver Lorz and Gerald Willmann, Enlargement versus Deepening: The Trade-off Facing Economic Unions, November 2008

2456 Alfons J. Weichenrieder and Helen Windischbauer, Thin-Capitalization Rules and Company Responses, Experience from German Legislation, November 2008

2457 Andreas Knabe and Steffen Rätzel, Scarring or Scaring? The Psychological Impact of Past Unemployment and Future Unemployment Risk, November 2008

2458 John Whalley and Sean Walsh, Bringing the Copenhagen Global Climate Change Negotiations to Conclusion, November 2008

2459 Daniel Mejía, The War on Illegal Drugs in Producer and Consumer Countries: A Simple Analytical Framework, November 2008

2460 Carola Frydman, Learning from the Past: Trends in Executive Compensation over the Twentieth Century, November 2008

2461 Wolfgang Ochel, The Political Economy of Two-tier Reforms of Employment Protection in Europe, November 2008

2462 Peter Egger and Doina Maria Radulescu, The Influence of Labor Taxes on the Migration of Skilled Workers, November 2008

2463 Oliver Falck, Stephan Heblich and Stefan Kipar, The Extension of Clusters: Differencein-Differences Evidence from the Bavarian State-Wide Cluster Policy, November 2008 
2464 Lei Yang and Keith E. Maskus, Intellectual Property Rights, Technology Transfer and Exports in Developing Countries, November 2008

2465 Claudia M. Buch, The Great Risk Shift? Income Volatility in an International Perspective, November 2008

2466 Walter H. Fisher and Ben J. Heijdra, Growth and the Ageing Joneses, November 2008

2467 Louis Eeckhoudt, Harris Schlesinger and Ilia Tsetlin, Apportioning of Risks via Stochastic Dominance, November 2008

2468 Elin Halvorsen and Thor O. Thoresen, Parents' Desire to Make Equal Inter Vivos Transfers, November 2008

2469 Anna Montén and Marcel Thum, Ageing Municipalities, Gerontocracy and Fiscal Competition, November 2008

2470 Volker Meier and Matthias Wrede, Reducing the Excess Burden of Subsidizing the Stork: Joint Taxation, Individual Taxation, and Family Splitting, November 2008

2471 Gunther Schnabl and Christina Ziegler, Exchange Rate Regime and Wage Determination in Central and Eastern Europe, November 2008

2472 Kjell Erik Lommerud and Odd Rune Straume, Employment Protection versus Flexicurity: On Technology Adoption in Unionised Firms, November 2008

2473 Lukas Menkhoff, High-Frequency Analysis of Foreign Exchange Interventions: What do we learn?, November 2008

2474 Steven Poelhekke and Frederick van der Ploeg, Growth, Foreign Direct Investment and Urban Concentrations: Unbundling Spatial Lags, November 2008

2475 Helge Berger and Volker Nitsch, Gotcha! A Profile of Smuggling in International Trade, November 2008

2476 Robert Dur and Joeri Sol, Social Interaction, Co-Worker Altruism, and Incentives, November 2008

2477 Gaëtan Nicodème, Corporate Income Tax and Economic Distortions, November 2008 